\title{
PARTISIPASI MASYARAKAT TERHADAP PEMBANGUNAN INFRASTRUKTUR JALAN TANI DESA TETEAJI KECAMATAN TELLU LIMPOE KABUPATEN SIDENRENG RAPPANG
}

\author{
1) Adam Latif, 2) Muhammad Rusdi, 3) Dedi Setiawan
}

IImu Pemerintahan, Fakultas IImu Sosial dan IImu Politik, Universitas Muhammadiyah Sidenreng Rappang ilmuadmpublik.ums@gmail.com

\begin{abstract}
Abstrak
Penelitian ini bertujuan untuk mengetahui bagaimana partisipasi masyarakat di Desa Teteaji, bagaimana pembangunan infrastruktur jalan tani di Desa Teteaji, dan bagaimana partisipasi masyarakat terhadap pembangunan infrastruktur jalan tani. Populasi dalam penelitian ini adalah 384 masyarakat petani yang dimana pengambilan sampel yang digunakan yaitu Simple Random Sampling, dengan teknik Simple Random Sampling dengan jumlah Sampel 79 masyarakat petani, Penelitian ini menggunakan Metode Deksriptif Kuantitatif. Teknik Pengumpulan data yang digunakan melalui observasi, kuesioner, dan studi pustaka.Teknik Analisis data yang digunakan adalah analisis tabulasi frekuensi, dan analilis regresi linear dengan menggunakan SPSS 21.0 for windows. Hasil penelitian ini menunjukkan bahwa rata-rata persentase partisipasi masyarakat di Desa Teteaji sebesar $61,6 \%$ dengan kategori baik dan pembangunan infrastruktur jalan tani di Desa Teteaji sebesar 70,2 \% dengan kategori baik. Untuk mengetahui besarnya pengaruh partisipasi masyarakat terhadap pembangunan infrastruktur jalan tani di Desa Teteaji Kecamatan Tellu Limpoe Kabupaten Sidenreng Rappang, yaitu dengan melihat nilai R2 atau R square. Hasil dari tabel Model Summary, Pada bagian ini ditampilkan nilai $R=0,896$ dan koefisien determinasi RSquare atau (R2) sebesar 0,955. Hal ini menunjukkan bahwa pembangunan infrastruktur jalan tani sejumlah $89,6 \%$ disebabkan oleh faktor partisipasi masyarakat sedangkan sisanya 10,4\% disebabkan oleh faktor-faktor lain yang tidak diteliti.
\end{abstract}

Kata Kunci : Partisipasi Masyarakat, Pembangunan Infrastruktur

\begin{abstract}
This study aims to find out how community participation in the village of Teteaji, how the construction of farm road infrastructure in the village of Teteaji, and how community participation in the construction of farm road infrastructure. The population in this study was 384 farming communities where the sampling used was Simple Random Sampling, with Simple Random Sampling techniques with a total sample of 79 farming communities, this study used a Quantitative Descriptive Method. Data collection techniques are used through observation, questionnaires, and library studies. Data analysis techniques used are frequency tabulation analysis, and linear regression analysis using SPSS 21.0 for windows. The results of this study indicate that the average percentage of community participation in Teteaji Village was $61.6 \%$ in the good category and the construction of farm road infrastructure in the Teteaji Village was $70.2 \%$ in the good category. To find out the magnitude of the effect of community participation on the construction of farm road infrastructure in Teteaji Village, Tellu Limpoe District, Sidenreng Rappang Regency, namely by looking at the value of $R 2$ or $R$ square. The results from the Model Summary table, in this section, the value of $R=0.896$ and the coefficient of RSquare determination or R2 are 0.955 . This shows that the construction of farm road infrastructure is $89.6 \%$ due to community participation while the remaining $10.4 \%$ is due to other factors not examined.
\end{abstract}

Keywords: Community Participation, Infrastructure Development

PRAJA | Volume 8| Nomor 1| Edisi Februari 2020 


\section{A. PENDAHULUAN}

Negara Indonesia ialah negara kesatuan yang berbentuk Republik". Dalam penyelenggaraan pemerintahan daerah Indonesia terdiri dari beberapa daerah/wilayah provinsi dan daerah/provinsi terdiri dari beberapa kabupaten/kota. Di setiap kabupaten/kota terdapat pemerintahan terendah yaitu desa/kelurahan. Pemerintah desa adalah menurut UU No 6 Tahun 2014 Tentang Desa adalah desa dan desa adat atau biasa disebut dengan nama lainnya, selanjutnya disebut desa, adalah kesatuan masyarakat hukum yang memiliki batas wilayah yang berwenangan untuk mengatur dan mengurus urusan pemerintahan, kepentingan masyarakat setempat berdasarkan prakarsa masyarakat, hak asal-usul, dan/atau hak tradisional yang diakui dan dihormati dalam sistem pemerintahan Negara Republik Indonesia. Pada umumnya, setiap program pembangunan masyarakat (termasuk pemanfaatan sumber daya lokal dan alokasi anggarannya) selalu ditetapkan sendiri oleh pemerintah pusat, yang dalam banyak hal lebih mencerminkan keinginan dan kebutuhan masyarakat banyak. Karena itu, partisipasi masyarakat dalam pembangunan perlu ditumbuhkan melalui dibukanya forum yang memungkinkan masyarakat banyak berpartisipasi langsung di dalam proses pengambilan keputusan khususnya program-program pembangunan di wilayah setempat atau di tingkat lokal.

Era reformasi telah membawa perubahan yang sangat besar dalam sistem pemerintahan di indonesia, sejak pelaksanaan otonomi daerah yang berlaku di indonesia mengalami perubahan yang cukup signifikan dimana pemerintah daerah diberi wewenang yang lebih besar dalam pengelolahan pembangunan di daerahnya masing-masing, sehingga kedudukan perencanaan semakin penting. Undang-undang Nomor 09 tahun 2015 tentang Pemerintahan Daerah. Pembangunan merupakan wujud pertanggungjawaban pemerintah terhadap pelaksanaan janji-janji politik yang banyak disampaikan dalam berbagai kontektasi pemilihan Pemimpin Daerah dan anggota legislatif. Penyusunan perencanaan pembangunan daerah menjadi suatu keharusan bagi setiap pemerintah daerah, baik provinsi, kabupaten/kota, kecamatan, desa/kelurahan.Menurut (Siagian, 2001) keberhasilan kegiatan pembangunan akan lebih terjamin apabila seluruh warga masyarakat membuat komitmen untuk turut berperan sebagai pelaku pembangunan dengan para anggota elit masyarakat sebagai panutan, pengarah, pembimbing, dan motivator. Menurut (Cakrawijaya, Riyant, \& Nuroji, 2015) infrastruktur merupakan sistem fisik yang menyediakan transportasi, pengairan, drainase, bangunan gedung dan fasilitas publik lainnya, yang dibutuhkan untuk memenuhi kebutuhan dasar manusia baik kebutuhan sosial maupun kebutuhan ekonomi. Pengertian ini merujuk pada infrastruktur sebagai suatu sistem dan dalam sebuah sistem infrastruktur adalah bagian-bagian berupa sarana dan prasarana (jaringan) yang tidak terpisahkan satu sama lain. Hal tersebut dikarenakan infrastruktur dalam sebuah sistem menopang sistem sosial dan sistem ekonomi sekaligus menjadi penghubung dengan sistem lingkungan.

Undang-undang Nomor 25 Tahun

2004 tentang Sistem Perencanaan Pembangunan Nasional. Maka diperlukan tingkat partisipasi tinggi dari masyarakat demi terwujudnya tata kelola pemerintahan yang lebih baik. Pelaksanaan pembangunan desa mengacu pada pencapaian tujuan pembangunan yaitu untuk mewujudkan kehidupan masyarakat pedesaan yang mandiri, maju, sejahtera dan berkeadilan. Musrenbang merupakan forum perencanaan yang dilaksanakan oleh lembaga publik yaitu pemerintah desa, bekerja sama dengan warga dan para pemangku kepentingan lainnya. Musrenbang yang bermakna akan mampu membangun kesepahaman kepentingan dan kemajuan desa, dengan cara memotret potensi dan sumber-sumber pembangunan yang tidak tersedian baik dari dalam maupun luar desa. Partisipasi masyarakat dalam pembangunan maju, sejahtera seringkali diartikan sebagai partisipasi masyarakat banyak (yang umumnya lebih miskin) untuk secara suka rela menyumbangkan tenaganya di dalam 
kegiatan pembangunan. Di lain pihak, lapisan yang diatasnya (yang umumnya terdiri atas orang-orang kaya) dalam banyak hal lebih banyak memperoleh manfaat dari hasil pembangunan, tidak dituntut sumbangannya secara proporsional. Karena itu, partisipasi masyarakat dalam pelaksanaan pembangunan desa harus diartikan sebagai pemerataan sumbangan masyarakat dalam bentuk tenaga kerja, uang tunai, dan atau beragam bentuk korban lainnya yang sepadan dengan manfaat yang akan diterima oleh masingmasing warga masyarakat yang bersangkutan, di samping itu, yang sering dilupakan dalam pelaksanaan pembangunan adalah partisipasi masyarakat dalam pemeliharaan proyekproyek pembangunan kemasyarakatan yang telah berhasil diselesaikan. Oleh karena itu, perlu adanya kegiatan khusus untuk mengorganisir warga masyarakat guna memelihara hasil-hasil pembangunan agar manfaatnya dapat terus dinikmati (tanpa penurunan kualitasnya) dalam jangka panjang.

Pembangunan di desa merupakan bagian terpenting dari upaya pembangunan nasional. Sejauh ini, partisipasi masyarakat masih terbatas pada keikutsertaan dalam pelaksanaan program-program kegiatan pemerintah, padahal partisipasi masyarakat tidak hanya diperlukan pada saat pelaksanaan tetapi juga mulai dari tahap perencanaan bahkan pengambilan keputusan. Skema baru otonomi daerah, yang didalamnya termuat semangat melibatkan masyarakat, dengan menekankan bahwa kualitas otonomi daerah akan ditentukan oleh sejauh mana keterlibatan masyarakat, maka dengan sendirinya harus ditunjukkan adanya saluran aspirasi masyarakat semenjak dini. Partisipasi masyarakat dalam pembangunan bukan hanya dilihat sebagai proses tetapi juga merupakan hasil akhir, yang mana partisipasi masyarakat adalah salah satu indikator yang mempengaruhi hasil pembangunan desa. Partisipasi masyarakat bukan lagi merupakan kewajiban, melainkan sudah merupakan hak bagi masyarakat untuk terjun langsung berpatisipasi/ ikut serta dalam setiap perencanaan atau kegiatan pembangunan, karena masyarakat mengetahui potensi dan kendala apa yang dihadapi, mereka yang memiliki kebebasan untuk memutuskan pelaksanaan suatu kegiatan pembangunan.Tujuan pembangunan suatu negara dilaksanakan pada hakikatnya adalah untuk mensejahterahkan masyarakat, demikian halnya dengan Negara Indonesia, dalam Pembukaan Undang-Undang Dasar 1945 dinyatakan bahwa tujuan pembangunan nasional Bangsa Indonesia adalah melindungi segenap bangsa dan seluruh tumpah darah Indonesia, memajukan kesejahteraan umum, mencerdaskan kehidupan bangsa, serta ikut melaksanakan ketertiban dunia. Untuk mewujudkan tujuan tersebut dilaksanakan pembangunan nasional, yaitu pembangunan manusia Indonesia seutuhnya dan pembangunan masyarakat seluruhnya, dalam mewujudkan tujuan program pembangunan pada setiap lembaga dibutuhkan suatum pola manejerial dalam pengelolahan pembangunan, pola manajerial tersebut dimaksudkan agar hasil pembangunan dan program-program pemerintahan lainnya saat dirasakan dan dinikmati manfaatnya oleh masyarakat. Salah satu hal yang dibutuhkan adalah kesadaran dan partisipasi aktif dari seluruh masyarakat dalam menunjang suksesnya pelaksanaan program pembangunan. Partisipasi masyarakat merupakan modal utama dalam upaya mencapai sasaran program pembangunan. Adanya partisipasi masyarakat akan mampu mengimbangi keterbatasan biaya dan kemanpuan pemerintah dalam pencapaian pelaksanaan program pembangunan tersebut.

Penyelenggaraan pembangunan desa diperlukan pengorganisasian yang mampu menggerakkan masyarakat untuk mampu berpartisipasi dalam melaksanakan pembangunan desa serta melaksanakan administrasi pembangunan desa. Dengan demikian diharapkan pembangunan dan pelaksanaan administrasi desa akan berjalan lebih baik, tidak hanya didasarkan pada tuntutan emosional yang sulit 
dipertanggungjawabkan kebenarannya.

Hal ini mengisyarakatkan bahwa

keikutsertaan masyarakat di dalam

perencanaan pembangunan desa

memang benar-benar sangat dibutuhkan

untuk mensinkronkan rencana

pembangunan desa yang akan

dilaksanakan dengan apa yang

dibutuhkan masyarakat dalam

meningkatkan kehidupan dan

penghidupannya di desa.

Berdasarkan penjelasan tersebut di atas, proses perencanaan pembangunan Desa di Teteaji dilakukan dengan musrenbang, dimana dalam perencanaan pembangunan telah dibuka kesempatan bagi seluruh warga untuk berpartisipasi. Keberhasilan pemerintah Kecamatan Tellu Limpoe pada umumnya dan pemerintah Desa Teteaji pada khususnya, dalam jangka panjang tidak hanya bergantung pada kepuasan masyarakat atas pelayanan yang diberikan, tapi juga atas ketertarikan, keikutsertaan dan dukungan dari masyarakat. Agar pembangunan berjalan sebagaimana yang kita harapkan, maka diperlukan partisipasi dari masyarakat dalam menajalankan aktivitas pembangunan. Partisipasi masyarakat dalam pelaksanaan pembangunan memerlukan kesadaran warga masyarakat akan kepentingan yang diterapkan adalah melalui strategi penyadaran. Demokrasi yang sehat tergantung pada bagaimana masyarakat termasuk masyarakat mendapatkan informasi yang baik dan dapat mempengaruhi pengambilan keputusan yang akan ditetapkan oleh pemerintah desa. Peran serta masyarakat langsung dalam perencanaan pembangunan sangat diperlukan dan perlu terus diperkuat dan ditingkatkan. Hasil observasi peneliti tanggal $12 \mathrm{~s} / \mathrm{d} 23$ November 2018 di Desa Teteaji Kecamatan Tellu Limpoe Kabupaten Sidenreng Rappang ditemukan masalah bahwa:

1. Masyarakat yang diundang, mereka enggan untuk hadir pada setiap musyawarah yang diadakan di desa karena alasan kesibukan aktivitas sehari-hari, di sini sangat terlihat kurangnya keinginan masyarakat untuk berpartisipasi dalam setiap perencanaan pembangunan khususnya pembangunan infrastruktur jalan tani apalagi pelaksanaan dan pemeliharaan hasil pembangunan, dari 60 sampai 80 undangan yang diedarkan yang hadir hanya berkisar 20 sampai 35 orang saja, data ini berdasarkan daftar hadir musyawarah desa Rencana pembangunan jangka menengah desa (RPJMDes) Tahun 2016-2020.

2. Partisipasi masyarakat di Desa Teteaji kurang berperan dikarenakan adanya anggapan sebagian masyarakat petani bahwa pembangunan desa merupakan tugas aparat desa atau pemerintah saja dan jika diadakan rapat atau gotong royong dalam pelaksanaan pembangunan, partisipasi tokoh masyarakat untuk turut serta sangatlah kurang, dengan alasan karena masih ada pekerjaan lain yang diutamakan yaitu pemenuhan kebutuhan seharihari, padahal dalam hal ini partisipasi masyarakat seperti swadaya, pikiran dan tenaga mereka sangat dibutuhkan terhadap pelaksanaan pembangunan Jalan tani di Desa Teteaji. Indikasi dari permasalahan itu adalah masih banyak lokasi lahan pertanian belum mempunyai akses jalan menuju jalan tani yang memadai, sehingga sangat menghambat masyarakat petani yang ingin berusaha tani di lahannya. Oleh karena itu, perlu pembangunan jalan tani dengan pengertian sebagai pembangunan baru, peningkatan kapasitas atau rehabilitasi jalan tani agar memenuhi standar teknis untuk dilalui kendaraan yang mengangkut sarana produksi pertanian, hasil pertanian dan alat mesin pertanian khususnya di Desa Teteaji.

Melihat uraian penjelasan diatas judu yang diangkat adalah"Partisipasi Masyarakat Terhadap Pembangunan Infrastruktur Jalan Tani Di Desa Teteaji Kecamatan Tellu Limpoe Kabupaten Sidenreng Rappang" dengan tujuan Untuk mengetahui partisipasi masyarakat di Desa Teteaji Kecamatan Tellu Limpoe Kabupaten Sidenreng Rappang, Untuk mengetahui pembangunan infrastruktur jalan tani di Desa Teaji Kecematan Tellu Limpoe Kabupaten sedenreng rappang dan Untuk mengetahui partisipasi masyarakat terhadap pembangunan 
infrastruktur jalan tani di Desa Teteaji Kecamatan Tellu Limpoe Kabupaten Sidenreng Rappang.

\section{PENGERTIAN PARTISIPASI}

Secara harfiah, partisipasi berasal dari kata bahasa inggris participation yang berarti peran serta. Partisipasi dapat diartikan sebagai bentuk peran serta atau keikutsertaan secara aktif atau pro aktif dalam suatu kegiatan. Sumarto dalam (Solekhan, 2014) menjelaskan bahwa partisipasi itu merupakan suatu proses yang memungkinkan adanya iteraksi yang lebih baik antar stakholders sehingga kesepakatan-kesepakatan dan tindakan yang bersifat inovatif lebih mungkin tercipta dalam proses deliberatif, dimana ruang untuk mendengarkan, belajar, reflektsi dan memulai suatu aksi bersama bisa terjadi.

Istilah partisipasi sering diartikan "keikutsertaan". Namun, secara umum belum ada pengertian baku. Hal ini disebabkan karena penggunaan istilah partisipasi itu sendiri tergantung dari ruang lingkup dan sudut pandang pemakaian istilah tersebut. Demikian halnya istilah patisipasi yang dimaksud dalam pembahasan ini, adalah dalam lingkup dan sudut pandang aktivitas masyarakat dalam dalam melaksanankan pembangunan. Oleh karena itu, partisipasi yang dikenal keikutsertaan masyarakat atau keterlibatan secara aktif warga masyarakat dalam berbagai kegiatan pembangunan. Menurut Ach. Wazir Ws., et al. dalam (Isbandi RukmintoAdi, 2007) partisipasi bisa diartikan sebagai keterlibatan seseorang secara sadar kedalam interaksi sosial dalam situasi tertentu. Dengan pengertian itu, seseorang bisa berpartisipasi bila ia menemukan dirinya dengan atau dalam kelompok, melalui secara proses berbagai dengan orang lain dalam hal nilai,tradisi, perasaan, kesetiaan, kepatuhan dan tanggung jawab bersama. Sumardi dalam (Zainuddin, 2017) mengatakan bahwa partisipasi berarti peran serta seseorang atau kelompok masyarakat dalam peroses pembangunan baik dalam bentuk pernyataan maupun dalam bentuk kegiatan dengan memberi masukan pikiran, tenaga, waktu, keahlian, dan atau materi, serta ikut memanfaatkan dan menikmati hasil-hasil pembangunan, sedangkan menurut (Mardikanto Totok, 2015) partisipasi merupakan keikutsertaan seseorang di dalam kelompok sosial untuk mengambil bagian dari kegiatan masyarakatnya, diluar pekerjaan atau profesinya sendiri.

Menurut Adisasmita dalam Ahmad Mustanir (2017:21), kata partisipasi telah sering kita dengar dalam kehidupan sehari-hari, baik yang di ucapkan para ahli maupun orang awam. Sampai saat ini belum ada pengertian atau defenisi yang dapat diterima secara umum tentang partisipasi. Hal ini disebabkan oleh adanya perbedaan sudut pandang yang dipakai dalam memberikan pengertian atau defenisi, sedangkan menurut Gaventa dan Valderama dalam Ruslan (2016:13) diartikan sebagai suatu kepedulian dengan perbagai bentuk keikutsertaan warga dalam pembuatan kebijakan dan pengambilan keputusan di berbagai gelanggang kunci yang mempengaruhi kehidupan mereka. Peters dalam Marselina (2016:22), partisipasi adalah keterlibatan seseorang dalam suatu kegiatan mulai dari menentukan tujuan, perencanaan, pelaksanaan dan monitoring dengan dilandasi oleh kesadaran akan tujuan itu. Pengertian partisipasi mana yang akan dipakai, sangat tergantung pada sistem pemerintahan yang dianut negara yang bersangkutan.

Menurut Davis dan Newstorm dalam (Remiswal, 2013) bahwa partisipasi adalah keterlibatan mental dan emosional orang-orang dalam situasi kelompok yang mendorong mereka untuk memberikan konstribusi pada tujuan kelompok dan berbagai tanggun jawab untuk mencapainya. Sedangkan (Remiswal, 2013) berpendapat bahwa partisipasi adalah kesediaan masyarakat secara sukarela untuk membantu kelangsungan program-program baik atas inisiatif lokal maupun pemerintahan yang tercermin dari pikiran, sikap dan tindakan mereka berdasarkan model kerangka partisipasi yang dikembang baik dalam tahap perencanaan, pelaksanaan, pengawasan maupun tahap pengambilan manfaat dari program yang terdapat di lingkungan 
tempat tinggal mereka tersebut.Menurut Thubany dalam Purnamasari (2006:23) partisipasi penuh dapat terwujud jika struktur kelembagaan memungkinkan warga untuk berpartisipasi dan memutuskan persoalan mereka sendiri sehari-hari dan representasi masyarakat yang terwakili secara proporsional di dalam setiap proses pengambilan kebijakan atas nama kepentingan bersama. Oleh karenanya, partisipasi masyarakat harus didasarkan pada (1) pembuatan keputusan, (2) penerapan keputusan, (3) menikmati hasil, dan (4) evaluasi hasil. Sementara empat aspek yang menjadi indikasi terbangunnya partisipasi, yakni :

a. Informasi atau akses lainnya;Akses, yaitu bahwa setiap warga masyarakat itu mempunyai kesempatan untuk mengakses atau memengaruhi pembuatan kebijakan, termasuk akses dalam layanan publik dan akses pada arus informasi.

b. Inisiatif (voice/suara) dan apresiasi warga (masukan),Akses, yaitu bahwa setiap warga masyarakat itu mempunyai kesempatan untuk mengakses atau memengaruhi pembuatan kebijakan, termasuk akses dalam layanan publik dan akses pada arus informasi.

c. Mekanisme pengambilan keputusan. Pengambilan keputusan, yaitu masyarakat bersama - sama Pemerintah Desa membuat keputusan atas dasar kesepakatan bersama dan untuk kepentingan serta kesejahteraan masyarakat bersama.

d. Kontrol pengawasan.Kontrol, yaitu bahwa setiap warga masyarakat mempunyai kesempatan dan hak untuk melakukan pengawasan terhadap jalannya pemerintahan.

Partisipasi masyarakat adalah ikut sertanya seluruh anggota masyarakat dalam memecahkan permasalahanpermasalahan masyarakat tersebut.Geddesian (dalam Irma Purnamasari, 2008:43) mengemukakan bahwa pada dasarnya masyarakat dapat dilibatkan secara aktif sejak tahap awal penyusunan rencana. Keterlibatan masyarakat dapat berupa:

a. Pendidikan melalui pelatihan. b. Partisipasi aktif dalam pengumpulan informasi.

c. Partisipasi dalam memberikan alternatif rencana dan usulan kepada pemerintah.

Menurut Juliantara (dalam Irma Purnamasari, 2008:45) substansi dari partisipasi adalah bekerjanya suatu sistem pemerintahan dimana tidak ada kebijakan yang diambil tanpa adanya persetujuan dari rakyat, sedangkan arah dasar yang akan dikembangkan adalah proses pemberdayaan, lebih lanjut dikatakan bahwa tujuan pengembangan partisipasi adalah:

a. Pertama, bahwa partisipasi akan memungkinkan rakyat secara mandiri (otonom) mengorganisasi diri, dan dengan demikian akan memudahkan masyarakat menghadapi situasi yang sulit, serta mampu menolak berbagai kecenderungan yang merugikan.

b. Kedua, suatu partisipasi tidak hanya menjadi cermin konkrit peluang ekspresi aspirasi dan jalan memperjuangkannya, tetapi yang lebih penting lagi bahwa partisipasi menjadi semacam garansi bagi tidak diabaikannya kepentingan masyarakat.

c. Ketiga, bahwa persoalan-persoalan dalam dinamika pembangunan akan dapat di atasi dengan adanya partisipasi masyarakat. (Juliantara, 2002: 89-90).

Partisipasi masyarakat menurut Isbandi (2007:27) adalah : keikutsertaan masyarakat dalam proses pengidentifikasian masalah dan potensi yang ada di masyarakat, pemilihan dan pengambilan peraturan Desa tentang alternatif solusi untuk menangani masalah, pelaksanaan upaya mengatasi masalah, dan keterlibatan masyarakat dalam proses mengevaluasi perubahan yang terjadi.

Untuk penelitian ini maka peneliti menggunakan pendapat Tangkilisan (2005: 32) bahwa partisipasi masyarakat dilihat dari :

a. Partisipasi dalam memberikan tanggapan informasi merupakan peran serta masyarakat dalam menanggapi semua informasi yang berkaitan dengan Musrenbang. 
b. Partisipasi dalam perencanaan pembangunan merupakan partisipasi masyarakat dalam membuat perencanaan dalam Musrenbang.

c. Partisipasi dalam operasional pembangunan merupakan peran serta masyarakat dalam membantu berjalannya pelaksanaan dengan ikut bekerja dan bergotong royong dalam pelaksanaan program pembangunan.

d. Partisipasi dalam menerima dan memelihara pembangunan merupakan merupakan peran serta masyarakat dalam memelihara hasil pembangunan melalui perawatan yang dilakukan secara bersama - sama oleh masyarakat.

Masyarakat mengandung

pengertian suatu keseluruhan kompleks hubungan manusia yang sangat luas sifatnya. Menurut Koentjaraningrat dalam (Mustanir \& Abadi, 2017) masyarakat adalah kesatuan hidup manusia yang berinteraksi menurut suatu sistem adat istiadat tertentu yang bersifat kontinyu dan terikat oleh rasa identitas bersama. Sedangkan menurut Soekanto dalam (Mustanir \& Abadi, 2017) masyarakat adalah suatu sistem dari kebiasaan dan tata cara dari wewenang dan kerja sama antara berbagai kelompok dan pengolahan dari pengawasan tingkah laku serta kebebasan manusia

Masyarakat adalah golongan besar atau kecil yang terdiri dari beberapa manusia yang dengan sendirinya bertalian secara golongan dan mempengaruhi satu sama lain. Saling mempengaruhi artinya pengaruh dan pertalian kebathinan yang terjadi dengan sendirinya yang menjadi unsur yang harus ada bagi masyarakat. Masyarakat bukan berarti penjumlahan orang-orang saja, tetapi diantara mereka harus ada pertalian satu sama lainnya yang merupakan kesatuan yang selalu berubah yang hidup karena proses dan menyebabkan perubahan dapat terjadi dalam kehidupan manusia Hasan, Shadili dalam (Mustanir \& Abadi, 2017). Totok Mardikanto dalam (Mustanir \& Razak, 2017) mengatakan bahwa partisipasi masyarakat merupakan keikutsertaan masyarakat dalam proses pengidentifikasian masalah dan potensi yang ada di masyarakat, pemilihan dan pengambilan keputusan tentang alternatif solusi untuk menangani masalah, pelaksanaan upaya mengatasi masalah, dan keikutsertaan masyarakat dalam proses menilai hasil akhir terhadap perubahan yang terjadi. Karakteristik dari partisipasi ini adalah, semakin mantapnya jaringan sosial (social network) yang "baru" yang membentuk suatu jaringan sosial bagi terwujudnya suatu kegiatan untuk mencapai tujuan tertentu yang di inginkan. Karena itu, partisipasi sebagai proses akan menciptakan jaringan sosial baru masing-masing berusaha untuk melaksanakan tahapan-tahapan kegiatan demi tercapainya tujuan akhir yang di inginkan masyarakat atau struktur sosial yang bersangkutan. Verhangen dalam (Aprilia Theresia dkk, 2014) menyatakan bahwa, partisipasi merupakan suatu bentuk khusus dari interaksi dan komunikasi yang berkaitan dengan pembagian : kewenangan, tanggung jawab, dan manfaat.

\section{INDIKATOR} MASYARAKAT

Menurut Adisasmita (Razak, 2019:3) mengemukakan bahwa indikator partisipasi masyarakat terdiri dari:

a. Partisipasi uang adalah model partisipasi yang digunakan untuk memperlancar usaha-usaha bagi pencapaian kebutuhan masyarakat.

b. Partisipasi tenaga adalah partisipasi dalam bentuk tenaga yang digunakan untuk pelaksanaan usaha-usaha guna menunjang keberhasilan suatu kegiatan.

c. Partisipasi buah pikiran adalah model partisipasi dalam hal penyumbangan ide, pendapat atau gagasan, baik dalam menyusun kegiatan maupun untuk memperlancar pelaksanaan kegiatan dan juga untuk menjadikannya kenyataan dengan memberikan pengalaman dan kemampuan guna mengembangkan kegiatan yang diikutinya.

d. Partisipasi dalam kegiatan pengambilan keputusan yaitu masyarakat ikut serta dalam setiap pembicaraan dalam rangka untuk mengambil keputusan yang berhubungan dengan kepentingan 
bersama. Sedangkan partisipasi representatif dilakukan dengan cara memberikan kepercayaan/amanah kepada orang yang dipercayai yang duduk dalam organisasi.

3. FAKTOR-FAKTOR MEMENGARUHI MASYARAKAT

Menurut Makmur dalam Safruddin (2015:32), bahwa faktor-faktor yang memengaruhi partisipasi masyarakat adalah:

a. Faktor Intern

1) Kesadaran / Kemauan masyarakat untuk ikut dalam kegiatan-kegiatan yang dilaksanakan.

2) Pendidikan, tingkat pendidikan masyarakat mempengaruhi tingkat kemauan masyarakat dalam memahami program pembangunan.

3) Pendapatan/Penghasilan, tingkat penghasilan masyarakat turut berpengaruh terhadap partisipasi masyarakat. Hal ini terlihat dari besar kecilnya sumbangan yang diberikan.

b. Faktor Ekstern

1) Kepemimpinan Pemerintahan / Aparat dalam mengarahkan masyarakat

2) Fasilitas / Peralatan dalam hal ini milik pemerintah.

\section{PENGERTIAN PEMBANGUNAN}

Pengertian pembangunan memiliki beragam definisi. Istilah pembangunan bisa saja diartikan berbeda oleh berbagai ahli. Namun secara umun pembangunan merupakan proses untuk melakukan perubahan. Pengertian pembangunan diartikan sebagai suatu "proses" pembangunan sebagai proses menggambarkan adanya pengembangan baik meliputi proses pertumbuhan ataupun perubahan dalam kehidupan bersama (organisasi) sosial dan budaya (Latif, 2019).Menurut Aprillia Theresia $d k k$. (2015:3), pembangunan adalah suatu proses atau rangkaian kegiatan yang tidak pernah kenal berhenti, untuk terus menerus mewujudkan perubahanperubahan dalam kehidupan masyarakat dalam rangka mencapai perbaikan mutu hidup, dalam situasi lingkungan kehidupan yang juga terus menerus mengalami perubahan-perubahan, sedangkan menurut Jacobus Ranjabar (2015:130), teori mula tentang pembangunan ditandai oleh kenyataan bahwasanya konsep pembangunan dianggap sama dengan pertumbuhan ekonomi. Rochajat Harun, (2012:3), secara sederhana pembangunan adalah perubahan yang berguna menuju suatu sistem sosial dan ekonomi yang diputuskan sebagai kehendak suatu bangsa. Pembangunan menurut Siagian dalam Nurman (2015:87) adalah suatu usaha atau rangkaian usaha pertumbuhan dan perubahan berencana yang dilakukan secara sadar oleh suatu bangsa, Negara dan pemerintah menuju modernitas dalam rangka pembinaan bangsa. Mardiakanto Totok dan Soebiato Poerwoko, (2015:3), pembangunan adalah suatu usaha atau proses perubahan demi tercapainya tingkat kesejahteraan atau mutu hidup suatu masyarakat serta individu-individu di dalamnya yang berkehendak dan melaksanakan pembangunan ini.

$$
\text { Menurut (Siagian, 2014) }
$$

pembangunan didefinisikan sebagai rangkaian uasaha mewujudkan pertumbuhan dan perubahan secara terencana dan sadar yang ditempuh oleh suatu negara bangsa menuju modernitas dala rangka pembinaan bangsa (nation building).Pembangunan merupakan segala uapaya yang terus menerus ditujuhkan untuk memperbaiki kehidupan masyarakat dan bangsa yang belum baik, atau untuk memperbaiki kehidupan yang sudah baik menjadi lebih baik lagi. Meskipun demikian, apapun maksud, tujuan, dan makna, yang terkadung dalam pengertian yang dimaksudkan dalam satu istilah yang sama yaitu pembangunan, kesemuanya akan selalu merujuk pada sesuatu yang memiliki arah positif, lebih baik dan lebih bermanfaat bagi kehidupan umat manusia secara individual maupun bagi masyarakatnya, Hadad (Latif, 2019). Nurman (2015:97), ada tiga tujuan inti dari suatu pembangunan, yaitu:

a. Peningkatan ketersediaan dan perluasan distribusi berbagai macam barang kebutuhan hidup yang pokok, seperti pangan, sandang, papan, 
pendidikan, kesehatan, dan perlindungan keamanan.

b. Peningkatan standar hidup yang tidak hanya berupa peningkatan pendapatan, tetapi juga meliputi penambahan penyediaan lapangan kerja, perbaikan kualitas pendidikan, serta peningkatan perhatian atas nilainilai sikap cultural dan kemanuasiaan dan kesemuanya itu tidak hanya utuk memperbaiki kesejahteraan materill, melainkan juga menumbuhkan jati diri pribadi dan bangsa yang bersangkutan.

c. Perluasan pilihan-pilihan ekonomis dan sosial bagi setiap individu serta bangsa secara keseluruhan, yakni dengan membebaskan mereka dari belitan sikap menghamba dan ketergantungan, bukan hanya terhadap orang atau Negara-negara lain, maupun juga terhadap setiap kekuatan yang berpotensi merendahkan nilainilai kemanusiaan mereka.

Menurut Kuncoro (2010:20), pembangunan terdiri dari pembangunan fisik dan non fisik. Pembangunan fisik adalalah pembanguan yang dapat di rasakan langsung oleh masyarakat atau pembangunan yang tampak oleh mata pembangunan fisik misalnya berupa Infrastruktur, bangunan, fasilitas umum. Sedangkan pembangunan non fisik adalah jenis pembangunan yang tercipta oleh dorongan masyarakat setempat dan memiliki jangka waktu yang lama contoh pendidikan yang merata di seluruh daerah di indonesia, kesehatan yang semakin membaik, angka kematian saat kelahiran yang berkurang, masyarakat taat terhadap aturan yang berlaku, pariwisata yang semakin berkembang, kriminalitas yang terbenahi sedikit demi sedikit, ketertiban masyarakat. Fisik merupakan sesuatu yang dapat dilihat dan diraba seperti badan, bangunan, jalan, jembatan dan lain-lain. Setiap pembangunan fisik yang dilaksanakan harus memperhatikan halhal yang terdapat dalam perencanaan seperti dana, pengawasan, lokasi dan waktu pelaksanaan, keuntungan yang diterima masyarakat, sifat dan bentuk dari proyek itu sendiri, agar dalam pelaksanaan kegiatan akan berdaya guna dan berhasil bagi masyarakat. Pembangunan fisik berarti prasarana atau segala sesuatu yang merupakan penunjang utama terselenggaranya suatu proses baik itu usaha, pembangunan

$$
\text { Ketaren dalam Rahmah }
$$

(2016:36) adalah Pembangunan fisik sebagai suatu peningkatan kapasitas untuk memengaruhi masa depan mempunyai beberapa implikasi tertentu. Pertama, berarti memberikan perhatian terhadap kapasitas, terhadap apa yang diperlukan dilakukan untuk mengembangkan kemampuan dan tenaga guna membuat perubahan. Kedua, ia mencakup keadilan, perhatian yang berat sebelah kepada kelompok tertentu akan memecah belah masyarakat dan mengurangi kapasitasnya. Ketiga, penumbuhan kuasa dan wewenang, dalam pengertian bahwa hanya jika masyarakat mempunyai kuasa dan wewenang manfaat tertentu maka mereka akan menerima manfaat pembangunan, pada akhirnya pembangunan berarti perhatian yang sungguh-sungguh terhadap saling ketergantungan di dunia serta perlunya menjamin bahwa masa depan dapat ditunjang kelangsungannya.

\section{INDIKATOR INFRASTRUKTUR}

PEMBANGUNAN

Indikator

pembangunan

infrastruktur menurut Sjafrizal, (2014:26) adalah

a. Koordinasi merupakan keterpaduan antara pelaku pembangunan baik dalam institusi pemerintahan sendiri maupun pemerintahan antara pihak swasta dan masyarakat secara keseluruhan.

b. Singkronisasi adalah untuk mendorong proses pembangunan secara cepat dan efisien

c. Konsistensi adalah untuk dapat mewujudkan pembangunan sesuai dengan apa yang telah direncanakan semula, perlu dijamin semaksimal mungkin terdapatnya keterkaitan antara perencanaan, penganggaran, pelaksanaan, dan pengawasan.

d. Partisipasi adalah bagaimana partisipasi masyarakat tersebut dapat dimanfaatkan seoptimal mungkin dalam perencanaan.

e. Sumber daya secara efisien, efektif dan adil adalah tujuan dan fungsi utama 
dari perencanaan pembangunan dalam literatur adalah untuk menjamin terwujudnya penggunaan sumber daya, baik dana dan tenaga secara efektif, efisien dan adil.

\section{PEMBANGUNAN INFRASTRUKTUR}

Pembangunan infrastruktur merupakan salah satu aspek penting untuk mempercepat proses pembangunan nasional. Infrastruktur juga memegang peranan penting sebagai salah satu roda penggerak pertumbuhan ekonomi. Menurut Prof.Dr.Sunyoto Usman berpendapat bahwa infrstruktur sangat penting dalam menyediakan pelayanan untuk mendukung pembangunan ekonomi dan meningkatkan kualitas hidup. Dalam Undang-Undang Nomor 38 tahun 2004 tentang jalan, dijelaskan bahwa peran infrastruktur jalan adalah sebagai bagian prasarana transportasi yang mempunyai peran penting dalam bidang ekonomi, sosisal budaya, lingkungan hidup, politik, pertahanan dan keamanan, serta dipergunakan untuk sebesar-besar kemakmuran rakyat.

Selain itu, jalan sebagi prasarana bagi distribusi barang dan jasa merupakan urat nadi bagi kehidupan masyarakat, bangsa, dan negara. Kualitas infrastruktur, baik yang keras fisik (jalan, pelabuhan, irigasi), keras nonfisik (telepon, internet, listrik, air) memainkan peran vital karena merupakan penggerak perekonomian. Infrastruktur berhubungan dengan tiga hal (Hartanto,2004) pertama, dukungan dasar bagi pengembangan pabrik/industri, misalnya, listrik, jalan dan jaringan telekomunikasi. Kedua, biaya produksi dan distribusi, baik bahan baku dan produk jadi. Ketiga, keterkaitan dengan pasar dan proses pemasaran. Secara lebih rinci penyediaan infrastruktur terhadap pembangunan ekonomi adalah sebagai berikut : (1) mempercepat dan menyediakan barang-barang yang dibutuhkan, (2) tersedianya infrastruktur akan memungkinkan tersedianya barang-barang kebutuhan masyarakat dengan biaya lebih murah,
(3) infrastruktur yang baik dapat memperlancar transportasi yang pada gilirannya merangsang adanya stabilitasasi dan mengurangi disparitas harga antar daerah, (4) infrastruktur yang memperlancar jasa transportasi menyebabkan hasil produksi daerah dapat diangkut dan dijual kepasar (Basri, 2002)

Menurut World Bank kaitan infrastruktur jalan dengan biaya transportasi yaitu apabila kualitas infrastruktur jalan suatu daerah buruk maka akan mengakibatkan kenaikan biaya transportasi sehingga menurunkan daya saing produk-produk daerah tersebut dibanding produk daerah yang lain. sebagai contoh tingginya biaya transportasi barangbarang bernilai tinggi seperti udang dari belahan Timur Indonesia ke pusatpusat pemrosesan di pulau jawa melambungkan harga mereka ketitik yang terlalu mahal untuk diekspor, dan juga lebih murah untuk mengimpor buah jeruk dari Cina dibanding mengirimkan dari pulau Kalimantan ke pulau Jawa. Buruknya kualitas jalan di suatu daerah atau negara menempatkan biaya transportasi yang lebih tinggi dibanding dengan suatu daerah yang memiliki infrastruktur jalan yang baik. Ongkos-ongkos angkutan secara teoritis pada dasarnya dapat dibagi dalam dua golongan besar, yaitu sebagai berikut: 1. Variable expenses, yaitu pengeluaran-pengeluaran yang jumlahnya cenderung untuk berubahubah kira-kira secara proposional dengan tergantung kepada volume angkutan dari lalu lintas (traffic). Ongkos transportasi ini seringkali disebut pula sebagai pengeluaran langsung (direct expenses). 2. Fixed expenses, yaitu pengeluaranpengeluaran yang jumlahnya sekurangkurangnya dalam jangka pendek adalah tetap dan tidak tergantung pada volume angkutan dari traffic yang bersangkutan. Ongkos ini disebut pula sebagai indirect expenses, constant expenses, dan overhead expenses. Pada umumnya kenaikan ongkos pengangkutan sedikit banyaknya akan mengakibatkan kenaikan harga 
barang-barang, pertama-tama pada barang-barang yang memerlukan jasa pengangkutan dan juga kemudian dapat menimbulkan kenaikan pula pada harga barang-barang lainnya. Hal ini disebabkan karena kenaikan ongkos pengangkutan itu menyebabkan naiknya ongkos-ongkos produksi serta ongkos-ongkos pemasaran barangbarang selanjunya para penjual pada umumnya akan membebankannya kepada para konsumen (Rustian Kamaluddin: 2003:38).

\section{B. METODE PENELITIAN}

Penelitian ini memiliki dua variabel, variabel pertama yaitu partisipasi masyarakat dan variabel kedua yaitu pembangunan infrastruktur. Jenis penelitian yang digunakan adalah menggunakan deskriptif kuantitatif yaitu metode yang lebih menekankan pada aspek pengukuran secara obyektif terhadap fenomena sosial. Untuk dapat melakukan pengukuran, setiap fenomena sosial dijabarkan kedalam beberapa komponen masalah, variabel dan indikator. Setiap variabel yang ditentukan dan diukur dengan memberikan simbolsimbol angka yang berbeda-beda sesuai dengan kategori informasi yang berkaitan dengan variabel tersebut Jamaluddin Ahmad (2015:48).

Populasi menurut (Ahmad, 2015) adalah kesimpulan dari keseluruhan pengukuran,obyek, atau individu yang sedang di kaji.populasi sering juga di sebut universeatau sekelompok obyek yang memiliki karakteristik yang sama,atau obyek lain yang mempunyai karakteristik sama seperti golongan darah.Menurut Sugiyono dalam (Ahmad, 2015) pengertian populasi adalah wilayah generalisasi yang terdiri atas:obyek/subyek yang mempunyai kualitas dan karakteristik tertentu yang ditetapkan oleh peneliti untuk dipelajari dan kemudian di tarik kesimpulanya, (Sugiyono,2011).Data yang diperoleh menunjukkan populasi penelitian pada masyarakat petani di Desa Teteaji berjumlah 384 petani.
Penelitian ini menggunakan simple random sampling dikarenakan seluruh anggota populasi diberikan peluang yang sama untuk menjadi sampel (probability sampling). Dengan menggunakan random sampling ini, sampel yang diambil adalah masyarakat petani yang ada di Desa Teteaji Kecamatan Tellu Limpoe Kabupaten Sidenreng Rappang.Jadi sampel yang Proporsional untuk penelitian ini adalah untuk dusun I dari 144 masyarakat petani diambil sampel 30 masyarakat petani, untuk dusun II dari 240 masyarakat petani diambil sampel sebanyak 49 dan sehingga jumlah keseluruhnnya adalah 79 masyarakat petani.

Teknik pengumpulan data yang digunakan yaitu Observasi, Angket / Kuesioner, Studi Pustaka, sedangkan teknik analisis data yang digunakan adalah Skala pengukuran data dilakukan dengan lebih menekankan pada pengukuran sikap, pendapat, dan persepsi seseorang tentang fenomena sosial yang menggunakan Skala Likert. Beberapa jawaban dari pertanyaan yang sesuai dengan tujuan penelitian diberi bobot nilai, dengan nilai tertinggi 5 dan nilai terendah

Rumus yang digunakan untuk menganalisis data dengan menggunakan tekhnik tabulasi frekuensi, yaitu:

Keterangan :

$$
\mathrm{P}=\frac{\mathrm{F}}{\mathrm{n}}=\times 100 \%
$$

$$
\begin{aligned}
& P=\text { Hasil Persentase } \\
& F=\text { Jumlah Frekuensi }
\end{aligned}
$$

Responden

$$
\mathrm{n}=\text { Jumlah Sampel }
$$

Perlu adanya penentuan skala Likert dalam responden kriteria jawaban, menurut Nazir (2005), bahwa untuk mencari jumlah interval menggunakan rumus sebagai berikut :

$$
\begin{aligned}
& \text { Interval } \quad(\mathrm{I}) \\
& \text { Nilai tertinggi-Nilai terendah } \\
& \hline
\end{aligned}
$$

2.) Penentuan rata-rata skor

Untuk menentukan rata-rata skor digunakan rumus:

$$
\begin{aligned}
& \text { Rata-rata skor } \\
& \frac{\text { Rata skor }(\mathrm{x})}{\text { Jumlah responden }(n)}
\end{aligned} \text { = }
$$

3.) Penentuan rata-rata persentase 


\author{
Rata-rata \\ $=\frac{\text { Rata }- \text { rata skor }}{\text { Karakteristik jawaban }} \times 100 \%$ \\ Untuk mengetahui bagaimana \\ partisipasi masyarakat terhadap \\ pembangunan infrastruktur jalan tani di \\ Desa Teteaji Kecamatan Tellu Limpoe \\ Kabupaten Sidenreng Rappang, maka \\ nilainya sebagai berikut : \\ 1. Rata-rata persentase $81 \%-100 \%$ \\ $=$ Selalu \\ 2. Rata-rata persentase $61 \%-80 \%$ \\ $=$ Sering \\ 3. Rata-rata persentase $41 \%-60 \%$ \\ $=$ Kadang-Kadang \\ 4. Rata-rata persentase $21 \%-40 \%$ \\ = Jarang \\ 5. Rata-rata persentase $0 \%-20 \%$ \\ $=$ Tidak Pernah
} persentase

\section{HASIL PENELITIAN DAN PEMBAHASAN}

Jadi setelah diakumulasikan dan didapatkan nilai rata-rata skor 3,07 dan nilai rata-rata persentase tanggapan responden tentang partisipasi uang adalah $61,4 \%$ yang berarti kategori sering. Sesuai dengan nilai hasil data dari responden di atas, maka disimpulkan bahwa sumbangan berupa uang yang diberikan dari masyarakat petani untuk pemerintah Desa Teteaji Kecamatan Tellu Limpoe Kabupaten Sidenreng Rappang pada saat tahapan pelaksanaan pembangunan infrastruktur jalan tani

Jadi setelah diakumulasikan dan didapatkan nilai rata-rata skor 3,08 dan nilai rata-rata persentase tanggapan responden tentang partisipasi tenaga adalah $61,6 \%$ yang berarti kategori sering. Sesuai dengan nilai hasil data dari responden di atas, maka disimpulkan bahwa keikutsertaan masyarakat petani dalam proses pelaksanaan pembangunan infrastruktur jalan tani di Desa Teteaji Kecamatan Tellu Limpoe Kabupaten Sidenreng Rappang

Jadi setelah diakumulasikan dan didapatkan nilai rata-rata skor 3,16 dan nilai rata-rata persentase tanggapan responden tentang partisipasi buah pikiran adalah

$63,2 \%$ yang berarti kategori sering. Sesuai dengan nilai hasil data dari responden di atas, maka disimpulkan bahwa bagaimana masyarakat petani memberikan ide pemikiran untuk pembangunan dan kemajuan di desa dalam proses pelaksanaan pembangunan infrastruktur jalan tani di Desa Teteaji Kecamatan Tellu Limpoe Kabupaten Sidenreng Rappang

Jadi setelah diakumulasikan dan didapatkan nilai rata-rata skor 3,01 dan nilai rata-rata persentase tanggapan responden tentang partisipasi dalam kegiatan pengambilan keputusan adalah $60,2 \%$ yang berarti kategori sering. Sesuai dengan nilai hasil data dari responden di atas, maka disimpulkan bahwa masyarakat bersama - sama pemerintah Desa membuat keputusan atas dasar kesepakatan bersama dan untuk kepentingan serta kesejahteraan masyarakat bersama khususnya dalam proses pelaksanaan pembangunan infrastruktur jalan tani di Desa Teteaji Kecamatan Tellu Limpoe Kabupaten Sidenreng Rappang

Jadi setelah diakumulasikan dan didapatkan nilai rata-rata skor 3,54 dan nilai rata-rata presentase tanggapan Responden 70 \% dikategorikan sering, hal ini didukung oleh indikator pembangunan infrastruktur jalan tanidan teori yaitu koordinasi. Sesuai dengan nilai hasil data dari responden di atas, maka disimpulkan bahwa proses untuk memastikan bahwa adanya kerjasasama antara pemerintah Desa Teteaji dengan masyarakat dalam pembangunan infrastruktur jalan tani

Jadi setelah diakumulasikan dan didapatkan nilai rata-rata skor 3,48 dan nilai rata-rata presentase tanggapan Responden 69 \% dikategorikan sering, hal ini didukung oleh indikator pembangunan infrastruktur jalan tani dan teori yaitu singkronisasi. Sesuai dengan nilai hasil data dari responden di atas, maka disimpulkan bahwa untuk dapat mendorong proses pembangunan infrastruktur jalan tani di Desa Teteaji secara lebih cepat dan efisien.

Jadi setelah diakumulasikan dan didapatkan nilai rata-rata skor 3,58 dan nilai rata-rata presentase tanggapan responden $71 \%$ dikategorikan sering, hal ini didukung oleh indikator pembangunan infrastrukturjalan tanidan teori yaitu 
konsistensi. Sesuai dengan nilai hasil data dari responden di atas, maka disimpulkan bahwa untuk mewujudkan pembangunan infrastruktur jalan tani di Desa Teteaji Kecamatan Tellu Limpoe Kabupaten Sidenreng Rappang sesuai dengan apa yang telah direncanakan semula, perlu dijamin semaksimal mungkin terdapatnya keterkaitan antara perencanaan, penganggaran, pelaksanaan, dan pengawasan.

Jadi setelah diakumulasikan dan didapatkan nilai rata-rata skor 3,68 dan nilai rata-rata presentase tanggapan Responden 73 \% dikategorikan sering, hal ini didukung oleh indikator pembangunan infrastrukturjalan tanidan teori yaitu partisipasi. Sesuai dengan nilai hasil data dari responden di atas, maka disimpulkan bahwa partisipasi masyarakat terhadap perencanaan pembangunan infrastruktur jalan tani di Desa Teteaji belum optimal dan perlu ditingkatkan lagi dengan mengikutsertakan masyarakat dalam setiap kegiatan yang dilakukan di desa, sering dari proses perencanaan, pengambilan keputusan, proses pelaksanaan pembangunan dan pemeliharaan hasil-hasil pembangunan yang telah dilaksanakan. Perlunya ada usaha pemerinatah desa untuk mendorong agar partisipasi masyarakat petani lebih dioptimalkan lagi, karena pembangunan bersentuhan langsung dengan kehidupan masyarakat desa.

Jadi setelah diakumulasikan dan didapatkan nilai rata-rata skor 3,44 dan nilai rata-rata presentase tanggapan responden $68 \%$ dikategorikan sering, hal ini didukung oleh indikator pembangunan infrastrukturjalan tani dan teori yaitu sumber daya secara efisien, efektif dan adil. Sesuai dengan nilai hasil data dari responden di atas, maka disimpulkan bahwa tujuan dan fungsi utama dari perencanaan pembangunan infrastruktur jalan tani dalam literatur adalah untuk menjamin terwujudnya penggunaan sumber daya, sering dana dan tenaga secara efektif, efisien dan adil.

\section{KESIMPULAN}

Berdasarkan uraian-uraian serta pembahasan pada bab terdahulu maka peneliti mencoba menarik kesimpulan sebagai berikut :

1. Partisipasi masyarakat petani di Desa Teteaji Kecamatan Tellu Limpoe Kabupaten Sidenreng Rappang sebesar $61,6 \%$ dengan kategori baik

2. Pembangunan infrastruktur pertanian di Desa Teteaji Kecamatan Tellu Limpoe Kabupaten Sidenreng Rappang sebesar 70,2 \% dengan kategori baik

3. Pengaruh partisipasi masyarakat terhadap pembangunan infrastruktur jalan tani di Desa Teteaji Kecamatan Tellu Limpoe Kabupaten Sidenreng Rappang setelah melakukan penelitian dengan pembagian kuesioner maka hasil olah spss versi 20.00 diperoleh nilai $R$ square atau $R^{2}$ yang menunjukkan bahwa partisipasi masyarakat memiliki pengaruh terhadap pembangunan infrastruktur jalan tani sebesar 89,6 \% kategori Sangat baik sedangkan sisanya 10,4 \% dipengaruhi oleh faktor lain yang tidak diteliti.

\section{E. REFERENSI}

Buku:

Ahmad, Jamaluddin. (2015). Metode penelitian Administrasi Publik Teori dan Aplikasinya (G. Media, ed.). Yogyakarta.

Aprilia Theresia dkk. (2014). Pembangunan Berbasis Masyarakat. Bandung: Alfabeta.

Aprillia Theresia dkk. 2015. Pembangunan Berbasis Masyarakat. Alfabeta. Bandung.

Elmi Sumiyarsono. (2010). Pengelolaan Prasarana Penyediaan Air Bersih Provinsi Sulawesi Tenggara Program Pascasarjana.

Kuncoro, Mudrajad. 2010. Masalah, Kebijakan, dan Politik, Ekonomika Pembangunan. Erlangga. Jakarta

Latif, D. (2019). Partisipasi Masyarakat 
Dalam Pembangunan Infrastruktur Di Desa Timoreng Panua Kecamatan Panca Rijang Kabupaten Sidenreng Rappang. MODERAT: Jurnal IImiah IImu Pemerintahan Universitas Galuh Ciamis, 5(1), 1-15. Retrieved from https://jurnal.unigal.ac.id/index.php/m oderat/article/view/1898

Mardikanto Totok, dan S. P. (2015). No Title. Bandung: Alfabeta.

Nurman. 2015.Strategi Pembangunan Daerah. Rajagrafindo Persada. Depok.

Razak, M. R. R. (2018). Terhadap Perwujudan Good Governance. Akmen Jurnal IImiah, 15(3), 476-496. Retrieved from https://ejurnal.stienobelindonesia.ac.id/index.php/akmen

Remiswal. (2013). Partisipasi Gender di Lingkungan Kumunitas. Yogyakarta: Graha IImu.

Rochajat Harun. 2012. Komunikasi Pembangunan dan Perubahan Sosial. Rajawali Pers. Jakarta.

Siagian, S. P. (2014). Administrasi Pembangunan (Konsep, Dimensi dan Strateginya) (P. B. Aksara, ed.). Jakarta.

Sjafrizal, 2014, Perencanaan Pembangunan Daerah Dalam Era Otonomi, Raja Grafindo Persada, Jakarta.

Solekhan. (2014). Penyelenggaraan Pemerintah Desa Berbasis Partisipasi Masyarakat. Malang: Setara Press.

Zainuddin, B. (2017). Teori-teori Mutakhir Dalam Perspektif IImu Administrasi Publik. Makassar: Phinatama Media.

Jurnal:

Razak. M.R.R, Harfia. 2019, Partisipasi Masyarakat di Daerah Pegunungan terhadap Perwujudan Good Governance

Mustanir, A., \& Abadi, P. (2017). Partisipasi Masyarakat Dalam Musyawarah Rencana Pembangunan Di Kelurahan Kanyuara Kecamatan Watang Sidenreng Kabupaten Sidenreng Rappang. Jurnal Politik Profetik, 5(2), 247-261. Retrieved from http://journal.uinalauddin.ac.id/index.php/jpp/article/vi ewFile/4347/3986\%0Ahttp://journal.ui nalauddin.ac.id/index.php/jpp/issue/vi ew/636 